finement in order to find out what language, if any, they would speak, these cases of children reared by wolves afford the only experimental test for determining whether language is an hereditary instinct or not. Two things have to be decided, and I suppose can be decided by competent judges :-

1. Are these stories physically possible? Will wolves, when they have ceased to suckle, and after they have driven away their own cubs, allow a human cub to remain with them?

2. Are the stories attested by witnesses who were capable of sifting evidence? The further question, whether English gentlemen and officers would wilfully have perverted the truth, need surely not be asked-certainly not in the case of Colonel Sleeman.

The fact that in the mythologies and traditions of people widely separated from each other, and apparently unconnected by language or religion, we meet with stories of children suckled by wolves, should be kept entirely out of sight for the present, for it would only serve to confuse the question before us. Let it first be settled whether the cases adduced are sufficiently attested; secondly, whether there are physically possible, and we shall then be better prepared to say whether they are real and historical elements in the story of Romulus and Remus, and other geds and heroes of antiquity, or whether such stories must be looked upon as simply miraculous, and treated in the same manner as all other mythological deposits, whether of ancient or modern growth.-Max Müller, Acadeny, Nov. 7, 1874.

(The Professor does not appear to haveseen Dr. Ireland's paper on this subject.)

\title{
Obituary.
}

Thomas W. Shiell, M.B.

It is with considerable regret we have to announce the deaths, since our last issue, of two of the Medical Superintendents of the District Hospitals for the Insane in Ireland, both much esteemed members of our Association. The first is that of Thomas W. Shiell, Esq., A.B., M.B., of the Enniscorthy Establishment, who was found dead in his bed, from heart disease, on the 19th of October last, having been in office since the opening of the institution in 1862, and all that time a most efficient and humane performer of his arduous duties, His sudden removal was a cause of the greatest grief to all, both patients and attendants, under his charge, as well as throughout the district, where he was highly and generally respected for his duly appreciated ability and conscientiousness as a public officer. Dr. Shiell, whose age was about 45 years, was married, but without issue; he had been previously an Assistant Surgeon in the Army, and was the son of the late Visiting Physician of the Clonmel Hospital for the Insane. The vacancy thus so unexpectedly caused has been filled up by the transference to it of Joseph Edmundson, Esq., M.D., the Resident Physician and Superintendent of the Castlebar District, at the head of which he had been since 1863, having been previously the Medical Superintendent of the Clonmel Auxiliary District Hospital for the Insane.

\section{Richard EATON, M.D.}

The other death referred to is that of Richard Eaton, M.D., the Resident Medical Superintendent of the Ballinasloe District Hospital for the Insane, who succumbed on the 7th ultimo, after a short illness, from the effects of pneumonia, at the premature age also of 45 years, the last eleven of which, viz., since 1863 , he had been in office at Ballinasloe ; always sustaining his responsible position in such a manner as to obtain unmixed praise from the higher authorities, and the love and esteem of all under his immediate professional charge. Prior to his appointment by the Irish Government to Ballinasloe, he had been Assistant Medical Officer for some time at the County Stafford Asylum, his departure from which was much regretted. 